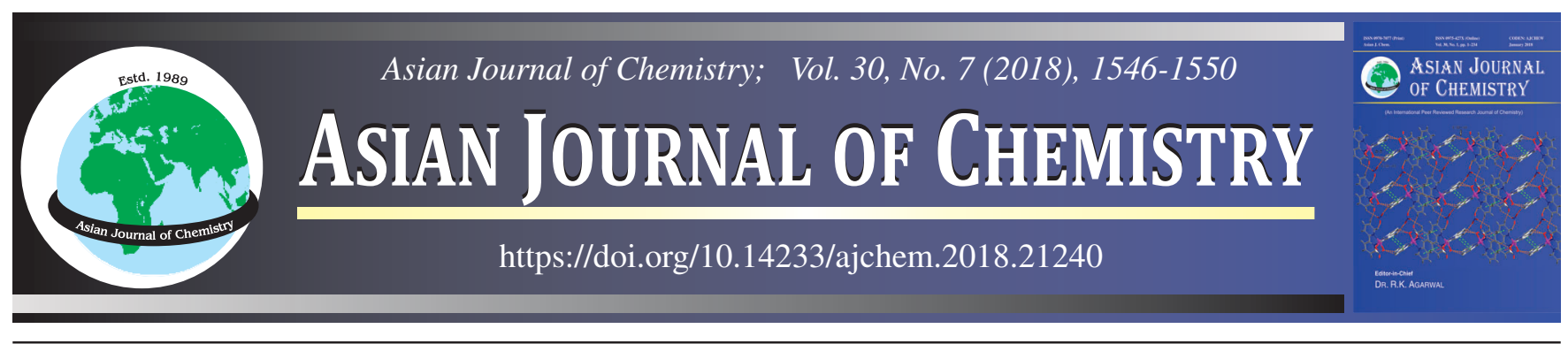

\title{
Quantification of Pyrethroid Residue in Food, Agricultural and Biological Samples
}

\author{
MAdHURANi ShUKLA ${ }^{1, *}$ and Kishore K. TiWARI ${ }^{2}$
}

${ }^{1}$ Department of Chemistry, Government College, Gobra Nawapara-493 881, India

${ }^{2}$ Department of Chemistry, Government Nagarjuna P.G. College of Science, Raipur-492 010, India

*Corresponding author: E-mail: shukla.madhu55@gmail.com

Received: 19 January 2018;

Accepted: 26 February 2018;

Published online: 31 May 2018;

AJC-18928

A simple and highly sensitive spectrophotometric method has been developed for the quantification of broadly used pyrethroid pesticides i.e. cypermethrin and fenvalerate. The developed method is based on alkaline hydrolysis of these pyrethroid pesticides to cyanide ion. The cyanide ion is further react with potassium iodide in acidic medium to liberate iodine and this liberated iodine oxidizes leucomalachite green to malachite green. The absorption maximum of the formed dye is measured at $600 \mathrm{~nm}$. Beer's law is obeyed in the concentration range of $0.08-0.72$ and $0.16-0.88 \mu \mathrm{g} / \mathrm{mL}$ for cypermethrin and fenvalerate, respectively. The molar absorptivity and Sandell's sensitivity were found to be $5.90 \times 10^{5} \mathrm{~L} \mathrm{~mol}^{-1} \mathrm{~cm}^{-1}$ and $0.00070 \mu \mathrm{g} \mathrm{cm}^{-2}$ for cypermethrin and $3.81 \times 10^{5} \mathrm{~L} \mathrm{~mol}^{-1} \mathrm{~cm}^{-1} \mathrm{and}_{0.0011 \mu \mathrm{g} \mathrm{cm}}^{-2}$ for fenvalerate pesticides. The developed method has been satisfactorily applied for the determination of cypermethrin and fenvalerate in their formulations and various food, agricultural and biological samples.

Keywords: Spectrophotometer, pH meter, Leucomalachite green, Pyrethroid pesticides, Food, Agricultural \& Biological samples. ᄂ - - - - - - - - - - - - - - - - - - - - - - - - - - - -

\section{INTRODUCTION}

At present time one of the fast growing global problem is pesticide residues which are present in food commodities caused serious hazardous effect on human health. Estimation of pesticides to human exposure can be determined by the levels present in the environment [1]. It has been reported that rigorous attack of insect pests in beans, brinjal and bitter gourd so that farmers used pesticides almost in every day for protection of their crops [2]. It is necessary to develop awareness to consumers for safety issue that to known what quantity of pesticides present in their food [3]. The pyrethroid insecticides having a nitrile group such as cypermethrin and fenvalerate, which are most widely used insecticides against a range of household and garden pests [4,5]. It was determined that pyrethroid insecticides i.e. cypermethrin and fenvalerate act as neurotoxins and attack to central nervous system of various insects. Both insecticides are moderately toxic by intake and by dermal absorption. High dermal exposure caused lack of sensation and itching, burning sensation and possible to death. It is carcinogenic and exert mutagenic effect to human [6,7]. The various techniques have been used for the determination of pyrethroid pesticides including cypermethrin and fenvalerate. These include GC-MS [8], thin layer chromatography [9], spectrophotometer [10,11], dispersive solid phase extraction and GC determination [12], high performance liquid chromatography, HPLC-MS [13-15] and gas chromatography [16-19] etc. Several spectrophotometric methods have also been reported for the determination of cypermethrin and fenvalerate insecticides. The aim of the proposed work is to develop a simple, rapid and accurate analytical method for the determination of broadly used cypermethrin and fenvalerate insecticide at micro gram levels. The developed method is based on alkaline hydrolysis of these pyrethroid pesticides to cyanide ion. The cyanide ion is further react with potassium iodide in acidic medium to liberate iodine and this liberated iodine oxidizes leucomalachite green to malachite green. The developed method has been satisfactorily applied to the determination of cypermethrin and fenvalerate in their formulations and various food, agricultural and biological samples.

\section{EXPERIMENTAL}

A Systronics (India) spectrophotometric model 166 with matched silica cells was used for all spectral measurements. A Systronics $\mathrm{pH}$ meter model no. 331 was used for $\mathrm{pH}$ measurements. All the chemicals used were of Analytical reagent grade or the best available quality. Double distilled water has been used throughout the study.

Cypermethrin and fenvalerate (Northern Minerals Limited, India): A stock solution of $1 \mathrm{mg} / \mathrm{mL}$ was prepared in ethanol. Working standards were prepared by appropriate dilution of the stock solution. 
Leucomalachite green (Sigma-Aldrich, S. Germany): 0.05 $\%$ of leucomalachite green was prepared by dissolving $25 \mathrm{mg}$ of leucomalachite green in $100 \mathrm{~mL}$ of water and $1.5 \mathrm{~mL}$ of 85 $\%$ phosphoric acid. Makeup to mark by using distilled water in a $500 \mathrm{~mL}$ of volumetric flask and shaking gently until the dye was dissolved completely. Phosphoric acid was dissolved the dye absolutely and to keep this solution stable for longer time [20].

Aqueous solution of sodium hydroxide (Loba Chemie, Mumbai) of $20 \%$ concentration was prepared. $0.1 \%$ aqueous solution of potassium iodide (Merck, Mumbai) was used. Aqueous solution $(6 \mathrm{M})$ of phosphoric acid was prepared. Acetate buffer ( $\mathrm{pH} 4.5$ ) was prepared by taking $1 \mathrm{M}$ sodium acetate trihydrate solution and $\mathrm{pH}$ was adjusted to 4.5 with using acetic acid. Then mixture was diluted up to $100 \mathrm{~mL}$ with distilled water [21].

Preparation of calibration curve for cypermethrin insecticides: Aliquots containing 2 to $18 \mu \mathrm{g}(0.08-0.72 \mu \mathrm{g} / \mathrm{mL})$ cypermethrin were taken in a series of $25 \mathrm{~mL}$ calibrated flasks. To this $1 \mathrm{~mL}$ of $20 \%$ sodium hydroxide solution was added and allowed to stand for $15 \mathrm{~min}$. at room temperature for complete hydrolysis. The reaction mixture neutralize and make slightly acidic with $4 \mathrm{M}$ phosphoric acid. Then added $1 \mathrm{~mL}$ of $0.1 \%$ potassium iodide solution to liberate iodine. After that added $1 \mathrm{~mL}$ of $0.05 \%$ of leucomalachite green with shaken thoroughly. Full colour developed after $15 \mathrm{~min}$. The resulting blue green dye was made up to the mark and measured at 600 $\mathrm{nm}$ against a reagent blank. Reagent blank gave negligible absorbance at this wavelength.

Preparation of calibration curve for fenvalerate insecticides: Aliquots containing 4 to $22 \mu \mathrm{g}(0.16-0.88 \mu \mathrm{g} / \mathrm{mL})$ fenvalerate were taken in a series of $25 \mathrm{~mL}$ calibrated flasks. To this $1 \mathrm{~mL}$ of $20 \%$ sodium hydroxide solution was added and allowed to stand for $15 \mathrm{~min}$. at room temperature for complete hydrolysis after which above procedure for the determination of cypermethrin was followed.

\section{RESULTS AND DISCUSSION}

Spectral characteristics: The maximum absorbance for both cypermethrin and fenvalerate pesticides obtained at 600 $\mathrm{nm}$. All spectral measurements were carried out against reagent blank (Fig. 1). Alkaline hydrolysis of cypermethrin and fenvalerate both pesticides give 3-(phenoxy)-2-hydroxy ethane nitrile which on further hydrolysis give cyanide ion. In acidic medium cyanide ion reacts with potassium iodide to liberate iodine. Liberated iodine selectively oxidized leucomalachite green to malachite green. The colour system obeys Beer's law in the range of 2 to $18 \mu \mathrm{g}$ of cypermethrin per $25 \mathrm{~mL}$ and 4 to $22 \mu \mathrm{g}$ of fenvalerate per $25 \mathrm{~mL}$ of final solution at $600 \mathrm{~nm}$ (Fig. 2). The molar absorptivity and Sandell's sensitivity were found to be $5.90 \times 10^{5} \mathrm{~L} \mathrm{~mol}^{-1} \mathrm{~cm}^{-1}$ and $0.00070 \mu \mathrm{g} \mathrm{cm}{ }^{-2}$ for cypermethrin and $3.8 \times 10^{5} \mathrm{~L} \mathrm{~mol}^{-1} \mathrm{~cm}^{-1}$ and $0.0011 \mu \mathrm{g} \mathrm{cm}{ }^{-2}$ for fenvalerate pesticides. The standard deviation and relative standard deviation were found to be \pm 0.00158 and $0.279 \%$ for cypermethrin and \pm 0.0011 and $0.254 \%$ for fenvalerate, respectively.

Absorption spectra: After alkaline hydrolysis cypermethrin and fenvalerate react with potassium iodide in acidic

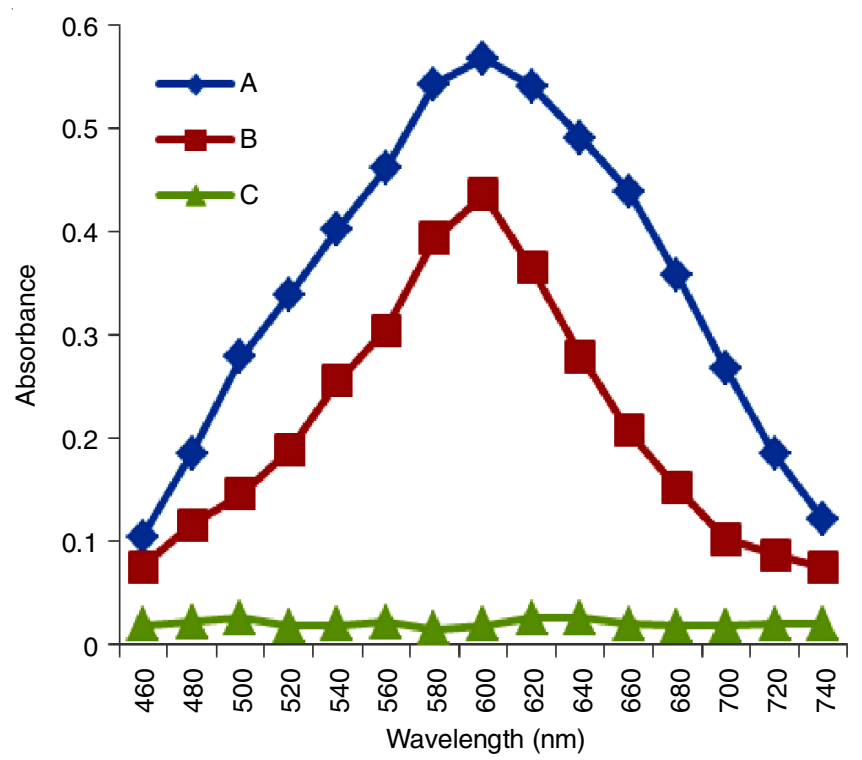

Fig. 1. Absorption spectra of the dye and reagent blank; (A) Concentration of cypermethrin $10 \mu \mathrm{g} / 25 \mathrm{~mL}$; (B) Concentration of fenvalerate 12 $\mu \mathrm{g} / 25 \mathrm{~mL}(\mathrm{C})$ Reagent blank

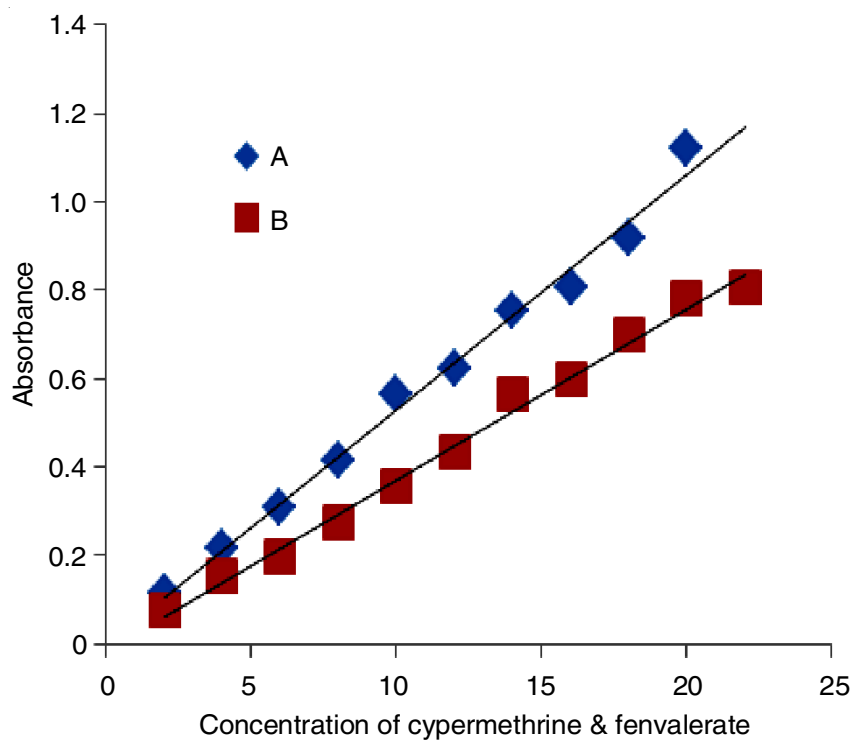

Fig. 2. Calibration curve for the determination of cypermethrin and fenvalerate pesticides; (A) Concentration of cypermethrin $\mu \mathrm{g} / 25 \mathrm{~mL}$; (B) Concentration of fenvalerate $\mu \mathrm{g} / 25 \mathrm{~mL}$

medium [22]. The liberated iodine oxidizes leucomalachite green dye. An acetate buffer ( $\mathrm{pH} 4.0-5.0)$ is required to maintained $\mathrm{pH}$ of the solution for colour development. The green colour of dye was developed by heating the above solution on a water bath at about $40{ }^{\circ} \mathrm{C}$ for $5 \mathrm{~min}$. The solution then diluted to $25 \mathrm{~mL}$ with water. The dye formed by both pesticides showed maximum absorbance at $600 \mathrm{~nm}$ against reagent blank. The reagent blank show negligible absorbance at this wavelength.

Effect of time and temperature: Hydrolysis of cypermethrin and fenvalerate to cyanide ion was studied at different temperatures. It was observed that the maximum hydrolysis was obtained with $20 \%$ of sodium hydroxide at temperature range of $30-40{ }^{\circ} \mathrm{C}$ as it gave maximum absorbance values with good stability [23,25] (Fig. 3). 


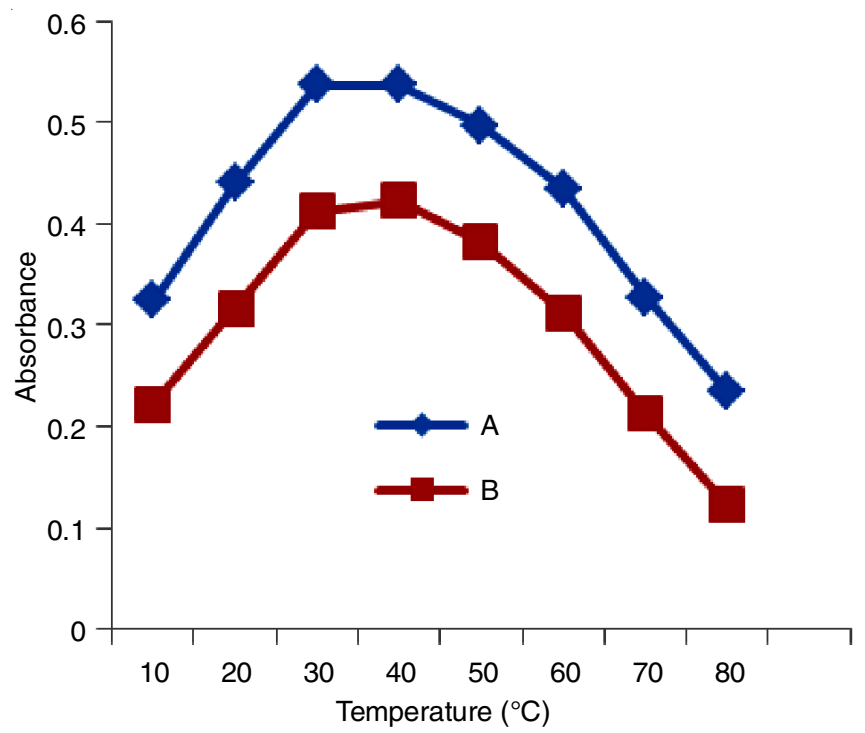

Fig. 3. Effect of temperature on absorbance of cypermethrin and fenvalerate; (A) Concentration of cypermethrin $10 \mu \mathrm{g} / 25 \mathrm{~mL}$ (B) Concentration of fenvalerate $12 \mu \mathrm{g} / 25 \mathrm{~mL}$

Effect of pH: The effect of $\mathrm{pH}$ on the colour reaction was studied. The constant absorbance values were obtained at $\mathrm{pH}$ range of 4.5-5.0. The acetate buffer solution used for maintaining the above $\mathrm{pH}$ range. The coloured species (malachite green dye) remain stable for more than 7 days under the optimum conditions (Fig. 4).

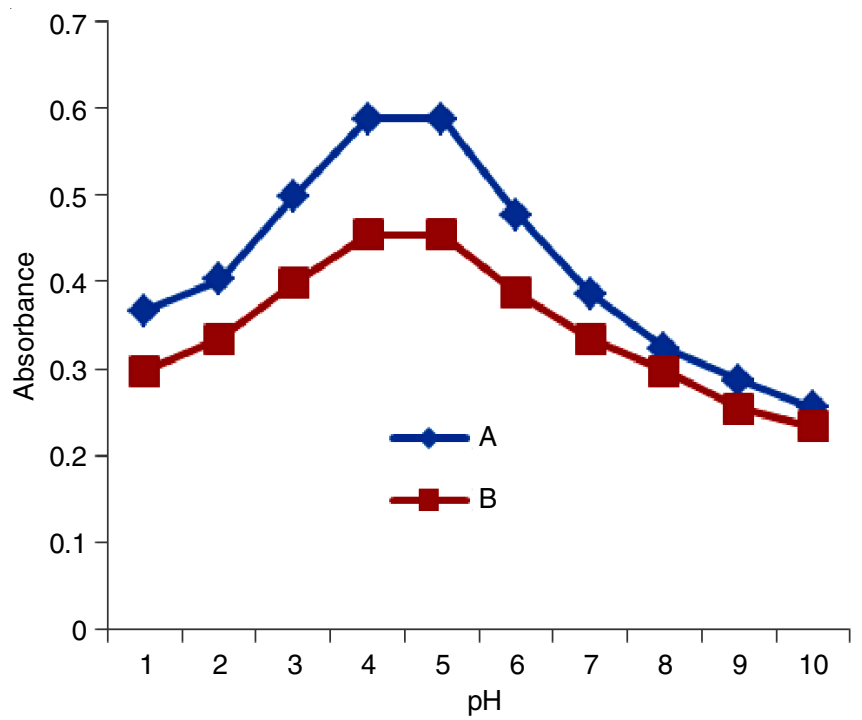

Fig. 4. Effect of $\mathrm{pH}$ in both pesticides on colour reaction; (A) Concentration of cypermethrin $10 \mu \mathrm{g} / 25 \mathrm{~mL}$; (B) Concentration of fenvelerate $12 \mu \mathrm{g} / 25 \mathrm{~mL}$

\section{Effect of the reagents concentration}

Effect of the concentration of cypermethrin and fenvalerate: The constant and maximum absorbance of the formed dye compound is found at the concentration range of $10 \mu \mathrm{g}$ of cypermethrin and $12 \mu \mathrm{g}$ of fenvalerate in a final solution volume of $25 \mathrm{~mL}$ (Fig. 5).

Effect of leuco malachite green: It was observed that $1 \mathrm{~mL}$ of leuco malachite green was sufficient for complete colour reaction (Fig. 6).

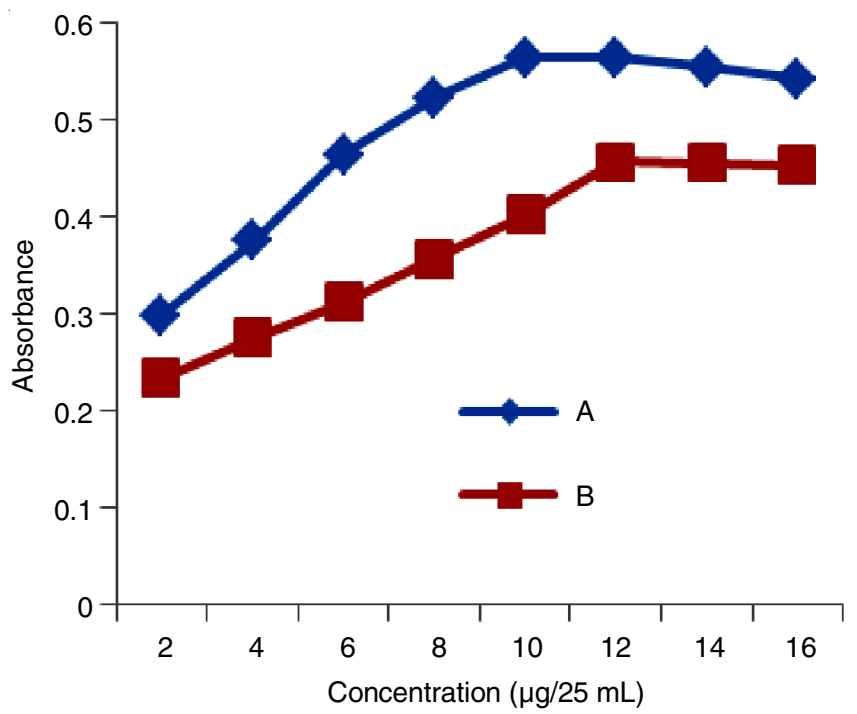

Fig. 5. Effect of concentration of cypermethrin and fenvalerate on absorbance; (A) Concentration of cypermethrin in $\mu \mathrm{g} / 25 \mathrm{~mL}$; (B) Concentration of fenvalerate in $\mu \mathrm{g} / 25 \mathrm{~mL}$

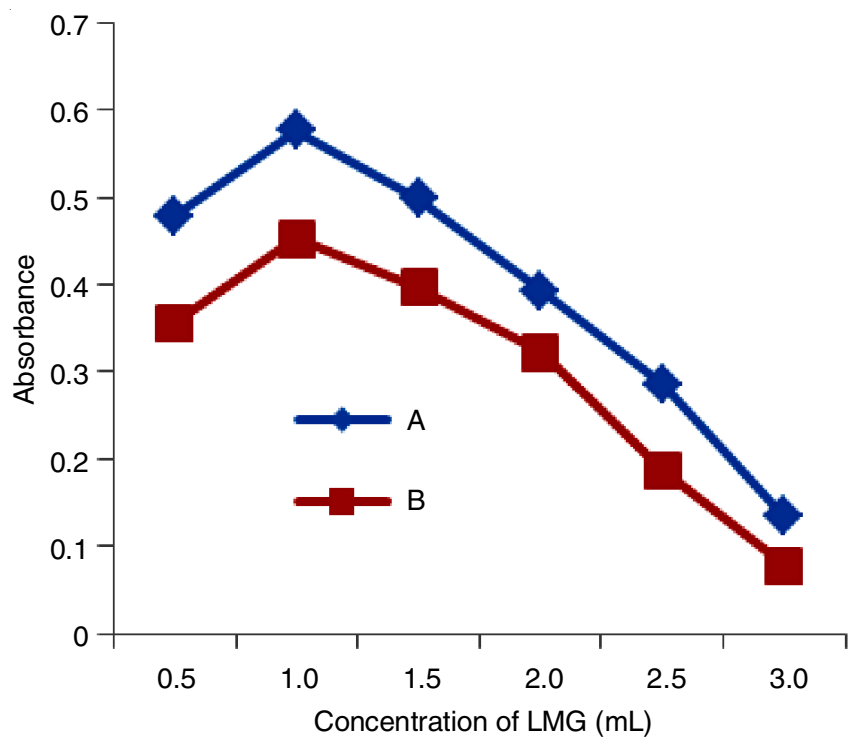

Fig. 6. Effect of the concentration of leuco malachite green (LMG) on absorbance of cypermethrine and fenvalerate; (A) Concentration of cypermethrin $10 \mu \mathrm{g} / 25 \mathrm{~mL}$; (B) Concentration of fenvalerate 12 $\mu \mathrm{g} / 25 \mathrm{~mL}$

Effect of sodium hydroxide: It was observed that maximum hydrolysis was observed with $1.5 \mathrm{~mL}$ of $20 \%$ sodium hydroxide for cypermethrin and $1 \mathrm{~mL}$ of $20 \%$ sodium hydroxide for fenvalerate at temperature range of $30-40{ }^{\circ} \mathrm{C}$ as it gave maximum absorbance values, good stability and quantitative results (Fig. 7).

Effect of potassium iodide: It was observed that $1 \mathrm{~mL}$ of $0.01 \%$ potassium iodide is sufficient for colour development (Fig. 8).

Effect of foreign species: The effect of some common pesticides and foreign species in the determination of cypermethrin and fenvalerate pesticides was studied which are probably interfere in the analysis. The known quantity of some pesticides and foreign species were added to the solution containing $10 \mu \mathrm{g}$ of cypermethrin and $12 \mu \mathrm{g}$ of fenvalerate in $25 \mathrm{~mL}$ of final solution. After hydrolysis of both pyrethroid 


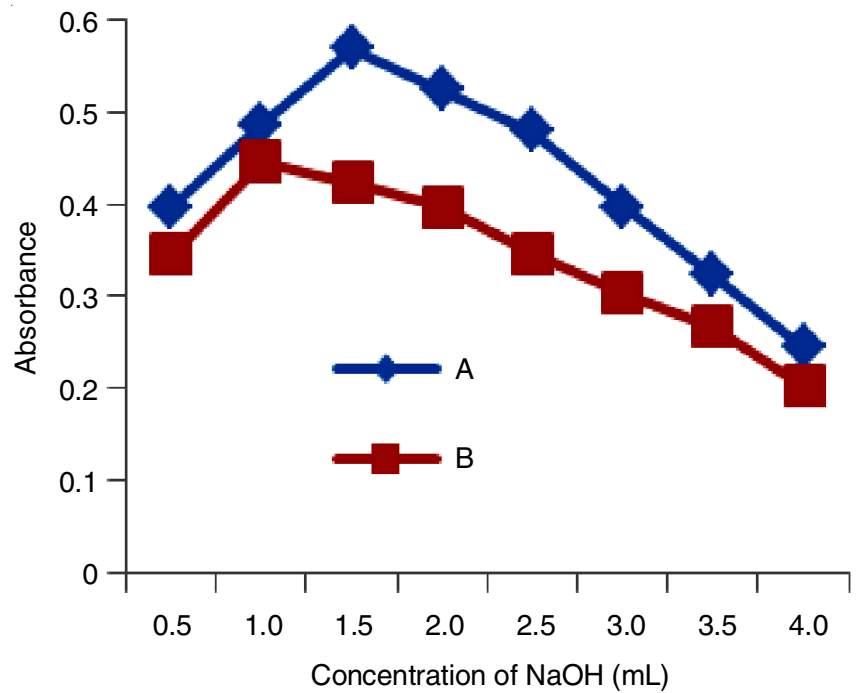

Fig. 7. Effect of the concentration of $\mathrm{NaOH}$ on absorbance of cypermethrin and fenvalerate; (A) Concentration of cypermethrin $10 \mu \mathrm{g} / 25 \mathrm{~mL}$; (B) Concentration of fenvalerate $12 \mu \mathrm{g} / 25 \mathrm{~mL}$

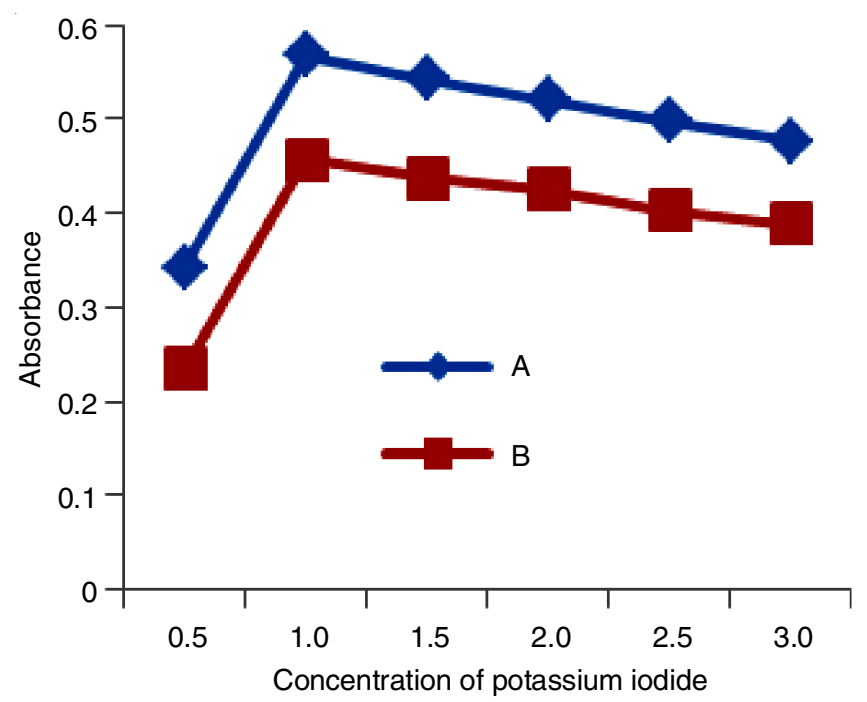

Fig. 8. Effect of the concentration of KI on absorbance of cypermethrin and fenvalerate; (A) Concentration of cypermethrin $10 \mu \mathrm{g} / 25 \mathrm{~mL}$; (B) Concentration of fenvalerate $12 \mu \mathrm{g} / 25 \mathrm{~mL}$

pesticides, the solution was analyzed by the above developed method. It was found that method is free from interferences of most of the pesticides and foreign species (Table-1).

Applications: The developed method has been used for the determination of cypermethrin and fenvalerate in various agricultural and biological samples. Agricultural runoff water which was collected from river, vegetables, fruits and grains which are collected from local market are analyzed. The
TABLE-1

EFFECT OF SOME FOREIGN SPECIES AND PESTICIDES IN CYPERMETHRIN \& FENVALERATE PESTICIDES

\begin{tabular}{lclc}
\hline $\begin{array}{c}\text { Foreign species/ } \\
\text { Pesticides }\end{array}$ & $\begin{array}{c}\text { Tolerance } \\
\text { limit* } \\
(\mu \mathrm{g} / \mathrm{mL})\end{array}$ & \multicolumn{1}{c}{$\begin{array}{c}\text { Foreign species/ } \\
\text { Pesticides }\end{array}$} & $\begin{array}{c}\text { Tolerance } \\
\text { limit* } \\
(\mu \mathrm{g} / \mathrm{mL})\end{array}$ \\
\hline Ethanol & 1800 & $\mathrm{Br}^{-}, \mathrm{Cl}^{-}$ & 420 \\
Phenol & 2000 & $\mathrm{Mg}^{2+}, \mathrm{Al}^{3+}$ & 350 \\
Benzene & 4800 & $\mathrm{Fe}^{3+}, \mathrm{Fe}^{2+}$ & 1000 \\
Toluene & 1200 & $\mathrm{Zn}^{2+}, \mathrm{Cu}^{2+}$ & 1200 \\
Aniline & 5000 & $\mathrm{Cresol}^{2+}$ & 400 \\
Trichloroacetic acid & 400 & Parathion, Malathion & 1200 \\
Benzaledehyde & 2000 & Paraquat, Diquat & 1200 \\
\hline *The amount having an error of $\pm 2 \%$ in the absorbance value.
\end{tabular}

developed method also used for analysis of cypermethrin and fenvalerate in its formulations.

Determination of cypermethrine and fenvalerate in agricultural runoff water: Agricultural runoff water from river of Rajim Kumbh, Raipur district (Chhattisgarh) was collected in glass bottle (amber). Interferences of chloride ions and humic acid first suppressed by adding $1 \mathrm{~mL}$ of $0.1 \mathrm{M}$ $\mathrm{Na}_{2} \mathrm{~S}_{2} \mathrm{O}_{3}$ solution in $1 \mathrm{~L}$ of water sample [25]. After that this solution was filtered and an aliquots of water samples were taken in $25 \mathrm{~mL}$ calibrated tube and added sodium hydroxide and kept in hot water bath for completion of hydrolysis. Pesticides were analyzed by using the above developed method (Table-2).

Determination of cypermethrin and fenvalerate in fruits and vegetables: Different fruits and vegetables collected from agricultural area where cypermethrin and fenvalerate has been sprayed. The fruits and vegetables of $25 \mathrm{~g}$ were mashed with $20 \mathrm{~mL}$ of ethanol-water and filtered through cotton cloth and centrifuged them for $10 \mathrm{~min}$ [26]. This filtrate then diluted with ethanol up to $50 \mathrm{~mL}$. $1 \mathrm{~mL}$ of this solution taken in 25 $\mathrm{mL}$ of calibrated tube and applied the developed method for determining both pyrethroid pesticides (Table-3).

Determination of cypermethrin and fenvalerate pesticides in biological samples: The validity of the developed method determined by recovery analysis of biological samples i.e. urine, blood. Before analysis, samples deproteinized with trichloroacetic acid. Known amount of cypermethrin and fenvalerate added in $2 \mathrm{~mL}$ of this deproteinized samples and sample was extracted with ethanol then analyzed as described developed method (Table-4).

\section{Conclusion}

The developed method is based on use of a new reagent leucomalachite green for the spectrophotometric determination of cypermethrin and fenvalerate in presence of each other. The

TABLE-2

DETERMINATION OF CYPERMETHRIN AND FENVALERATE IN AGRICULTURAL RUNOFF WATER SAMPLES

\begin{tabular}{|c|c|c|c|c|c|c|c|c|c|c|}
\hline \multirow{2}{*}{$\begin{array}{c}\text { Sample } \\
\text { No. }\end{array}$} & \multicolumn{2}{|c|}{ Found $(\mu \mathrm{g}) \mathrm{x}^{*}$} & \multicolumn{2}{|c|}{ Added $(\mu \mathrm{g}) \mathrm{y}$} & \multicolumn{2}{|c|}{ Total found $(\mu \mathrm{g}) \mathrm{z}$} & \multicolumn{2}{|c|}{ Difference $(\mu \mathrm{g}) \mathrm{z}$-x } & \multicolumn{2}{|c|}{ Recovery $\% \mathrm{z}$-x $\times 100 / \mathrm{y}$} \\
\hline & $\mathrm{I}$ & II & $\mathrm{I}$ & II & $\mathrm{I}$ & II & $\mathrm{I}$ & II & $\mathrm{I}$ & II \\
\hline 1 & 1.12 & 1.42 & 3.0 & 3.0 & 4.0 & 4.37 & 2.88 & 2.95 & 96.0 & 98.3 \\
\hline 2 & 1.14 & 1.37 & 6.0 & 6.0 & 7.06 & 7.28 & 5.92 & 5.91 & 98.6 & 98.5 \\
\hline 3 & 1.11 & 1.35 & 9.0 & 9.0 & 10.02 & 10.27 & 8.91 & 8.92 & 99.0 & 99.1 \\
\hline 4 & 1.15 & 1.45 & 12.0 & 12.0 & 12.96 & 13.30 & 11.81 & 11.85 & 98.4 & 98.7 \\
\hline 5 & 1.10 & 1.40 & 15.0 & 15.0 & 15.96 & 16.20 & 14.86 & 14.80 & 99.0 & 98.6 \\
\hline
\end{tabular}

*Mean of four repeated analysis; I: Cypermethrin, II: Fenvalerate 


\begin{tabular}{|c|c|c|c|c|c|}
\hline \multirow{2}{*}{ Sample No. } & \multicolumn{2}{|c|}{ Found $(\mu \mathrm{g}) \mathrm{x}^{*}$} & \multicolumn{2}{|c|}{ Added $(\mu \mathrm{g}) \mathrm{y}$} & \multirow[t]{2}{*}{$\mathrm{T}$} \\
\hline & $\mathrm{I}$ & II & $\mathrm{I}$ & II & \\
\hline Mango & 2.43 & 1.97 & 3.0 & 3.0 & 5 \\
\hline Apple & 2.32 & 2.12 & 6.0 & 6.0 & \\
\hline Tomato & 2.56 & 2.40 & 3.0 & 3.0 & \\
\hline Cucumber & 2.12 & 1.74 & 6.0 & 6.0 & \\
\hline Carrot & 2.27 & 2.11 & 9.0 & 9.0 & 1 \\
\hline Cauliflower & 2.78 & 2.56 & 12.0 & 12.0 & 12 \\
\hline \multicolumn{6}{|c|}{ *Mean of four repeated analysis; I: Cypermethrin, II: Fenvalerate } \\
\hline \multicolumn{6}{|c|}{$\begin{array}{l}\text { TABLE-4 } \\
\text { DETERMINATION OF CYPERMETHRIN AND } \\
\text { FENVALERATE IN VARIOUS BIOLOGICAL SAMPLES }\end{array}$} \\
\hline \multirow{2}{*}{ Sample } & \multicolumn{3}{|c|}{ Amount of pesticide $(\mu \mathrm{g})$} & \multirow{2}{*}{\multicolumn{2}{|c|}{ Recovery* $(\%)$}} \\
\hline & & & Found* & & \\
\hline \multicolumn{6}{|c|}{ Cypermethrin } \\
\hline \multirow{2}{*}{ Urine } & \multirow{2}{*}{\multicolumn{2}{|c|}{$\begin{array}{l}3 \\
6\end{array}$}} & 2.88 & \multicolumn{2}{|l|}{96.0} \\
\hline & & & 5.85 & \multicolumn{2}{|l|}{97.5} \\
\hline \multirow{2}{*}{ Blood } & \multicolumn{2}{|c|}{3} & 2,86 & 95.3 & \\
\hline & & & 5.79 & 96.5 & \\
\hline \multicolumn{6}{|c|}{ Fenvalerate } \\
\hline \multirow{2}{*}{ Urine } & & & 2.87 & \multicolumn{2}{|l|}{95.6} \\
\hline & & & 5.84 & \multicolumn{2}{|l|}{97.3} \\
\hline \multirow{2}{*}{ Blood } & & & 2.85 & \multicolumn{2}{|l|}{95.0} \\
\hline & & & 5.84 & \multicolumn{2}{|l|}{97.3} \\
\hline
\end{tabular}

*Mean of four replicate analyses

\begin{tabular}{lcc}
\multicolumn{3}{c}{ TABLE-5 } \\
SPECTRAL CHARACTERISTICS OF THE PROPOSED METHOD \\
\hline Parameters & Cypermethrin & Fenvalerate \\
\hline Maximum absorbance $(\mathrm{nm})$ & 600 & 600 \\
Beer's law conc. range $(\mu \mathrm{g} / \mathrm{mL})$ & $0.08-0.72$ & $0.16-0.88$ \\
Molar absorptivity $\left(\mathrm{L} \mathrm{mol}^{-1} \mathrm{~cm}^{-1}\right)$ & $5.90 \times 10^{5}$ & $3.8 \times 10^{5}$ \\
Sandell's sensitivity $\left(\mu \mathrm{cm}^{-2}\right)$ & 0.00070 & 0.0011 \\
Standard deviation & \pm 0.0015 & \pm 0.0011 \\
Relative standard deviation $(\%)$ & 0.279 & 0.254 \\
Correlation coefficient & 0.995 & 0.996 \\
Slope $(\mathrm{m})$ & 0.053 & 0.038 \\
Intercept $(\mathrm{C})$ & 0.0006 & 0.0103 \\
Relative error & 0.01 & 0.01 \\
Absolute error & 0.01 & 0.01 \\
Limit of detection $\left(\mu \mathrm{g} \mathrm{mL} \mathrm{m}^{-1}\right)$ & 0.0249 & 0.0346 \\
Limit of quantification $\left(\mu \mathrm{g} \mathrm{mL} \mathrm{mL}^{-1}\right)$ & 0.0754 & 0.1049 \\
\hline
\end{tabular}

method offers cost effectiveness, simple and sensitive. This method is much better alternative from other costly instrumental methods. Easy availability of the reagent, stability of the colour development, reproducibility and free from a large number of interfering species are the reason for increasing the importance of the method.

\section{ACKNOWLEDGEMENTS}

The authors are thankful to Principal and Head, Department of Chemistry, Government Nagarjuna P.G. College of Science, Raipur, India for providing laboratory facilities.

\section{REFERENCES}

1. A. Tahir, I. Ahmad and S. Tahir, Pak. J. Bot., 43, 1133 (2011).

2. M.S. Ahmed, M.A. Sardar, M.A. Haque and K.H. Kabir, Bangladesh J. Zool., 33, 57 (2005).
3. M.S. Ahmed, A. Begum, M.A. Rahman, M.W. Akon and M.A.Z. Chowdhury, Agriculturists, 14, 38 (2017);

https://doi.org/10.3329/agric.v14i2.31346.

4. Y. Mahboubeh, B. Mehran, A.A.M. Sharif and A.M. Khaneghah, Adv. Environ. Biol., 6, 2434 (2012).

5. J.A. Christine and D.M. James, J. AOAC Int., 89, 1425 (2006).

6. D.P. Weston, R.W. Holmes, J. You and M.J. Lydy, Environ. Sci. Technol., 39, 9778 (2005); https://doi.org/10.1021/es0506354.

7. S.P. Bradbury and J.R. Coats, Rev. Environ. Toxicol. Chem., 108, 133 (1989).

8. A. Ramesh and P.E. Ravi, J. Chromatogr. B Analyt. Technol. Biomed. Life Sci., 802, 371 (2004);

https://doi.org/10.1016/j.jchromb.2003.12.016.

9. J. Sherma, Acta Chromatogr., 15, 5 (2004).

10. E.D. Caldas, M.H. Conceiçao, M.C.C. Miranda, L.C.K. De Souza and J.F. Lima, J. Agric. Food Chem., 49, 4521 (2001); https://doi.org/10.1021/jf010124a.

11. E.K. Janghel, J.K. Rai, M.K. Rai and V.K. Gupta, J. Braz. Chem. Soc., 18, 590 (2007); https://doi.org/10.1590/S0103-50532007000300015.

12. A.A. Barakat, H.M.A. Badawy, E. Salama, E. Attallah and G. Maatook, J. Food Agric. Environ., 5, 97 (2007).

13. A. Abad, M.-J. Moreno, R. Pelegrí, M.-I. Martínez, A. Sáez, M. Gamón and A. Montoya, J. Agric. Food Chem., 49, 1707 (2001); https://doi.org/10.1021/jf0012493.

14. D. Debayle, G. Dessalces and M.F. Grenier-Loustalot, Anal. Bioanal. Chem., 391, 1011 (2008); https://doi.org/10.1007/s00216-008-2003-2.

15. S. Islam, N. Afrin, M.S. Hossain, N. Nahar, M. Mosihuzzam and M.I.R. Mamun, Am. J. Environ. Sci., 5, 325 (2009); https://doi.org/10.3844/ajessp.2009.325.329.

16. B. Kumari, J. Agric. Biol. Sci., 3, 6 (2008).

17. J. Fenoll, P. Hellín, C.M. Martínez, M. Miguel and P. Flores, Food Chem., 105, 711 (2007); https://doi.org/10.1016/j.foodchem.2006.12.060.

18. A. Lal, G. Tan and M. Chai, Anal. Sci., 24, 231 (2008); https://doi.org/10.2116/analsci.24.231.

19. P.C. Abhilash, V. Singh and N. Singh, Food Chem., 113, 267 (2009); https://doi.org/10.1016/j.foodchem.2008.07.004.

20. K.K. Tiwari, J. Chin. Chem. Soc., 57, 105 (2010); https://doi.org/10.1002/jccs.201000017.

21. H.D. Revanasiddappa, B.P. Dayananda and T.N.K. Kumar, Environ. Chem. Lett., 5, 151 (2007); https://doi.org/10.1007/s10311-007-0097-y.

22. E.Y. Backheet, K.M. Emara, H.F. Askal and G.A. Saleh, Analyst, 116, 861 (1991); https://doi.org/10.1039/an9911600861.

23. V.B. Patil, M.V. Sevalkar and S.V. Padalikar, Analyst, 117, 75 (1992); https://doi.org/10.1039/an9921700075.

24. R.S. Dhundhel and M.K. Rai, Asian J. Biochem. Pharm. Res., 3, 381 (2011).

25. B.K. Priya, P. Subrahmanyam, K. Dakshayani and P. Chiranjeevi, E-J. Chem., 4, 480 (2007); https://doi.org/10.1155/2007/296049.

26. V. Agrawal and V.K. Gupta, Fresenius J. Anal. Chem., 345, 720 (1993); https://doi.org/10.1007/BF00325842. 